\title{
An Experimental Study of Flexural Strength of Reinforced Concrete Beam Due To Corrosion
}

\author{
Naga Chaitanya $C^{\mathrm{a}}$, Vamsi Krishna $\mathrm{B}^{\mathrm{b}}$ \\ a. Research Scholar (M-Tech), Malla Reddy Engineering College (Autonomous), Secunderabad-500 100 \\ b Assistant Professor, Malla Reddy Engineering College(Autonomous), Secunderabad -500 100
}

\begin{abstract}
Reinforced concrete beams are normally designed as under reinforced to provide ductile behavior such as the tensile moment of resistance. In coastal environment reinforcement corrosion is an obvious cause of deterioration of concrete structure, which affects the durability and service of reinforced concrete structure. Structural stability is majorly influenced by strength of concrete. Flexural strength is a measure of the tensile strength of concrete, in other words it is a measure of a resistance against failure in bending. The main aim of this study is to analyze the strength, experimentally; of corroded beams using Ordinary Portland cement. Accelerated corrosion technique was adopted to corrode the beam experimentally. The corrosion was measured using Applied Corrosion monitoring instrument. Beam specimens are prepared using M20 grade concrete for OPC. Beam specimens casted are tested as vertical cantilever beam in specially prepared loading setup and load deflection behavior is studied.
\end{abstract}

Keywords: Applied Corrosion Monitoring, Flexural strength, Load deflection, Ordinary Portland cement Reinforced concrete, Tensile strength.

\section{Introduction}

Flexure or bending is commonly encountered in structural elements such as beams and slabs which are transversely loaded. Flexural strength is measure of the tensile strength of OPC concrete, in other words it is a measure of a resistance against failure in bending. Although the probability of the structures being flexure deficient is low, failures have occurred due to a variety of factors: errors in design calculations and improper detailing of reinforcement, construction fails or poor construction practices, changing the function of a structure from a lower service load to a higher service load, seismic and wind action, reduction or total loss of reinforcement steel area causing the corrosion in service environments.

Corrosion is caused by the destructive attack of chloride ions penetrating by diffusion or other penetration mechanisms from the outside, by incorporation into the opc concrete mixture, by carbonation of the cement cover, or their combination (Cabrera, 1996). Carbonation of concrete or penetrations of acidic gases into the concrete causes of reinforcement corrosion. Besides these there are few factors, some related to the concrete quality, such as w/c ratio, cement content, impurities in the concrete ingredients, presence of surface cracking, etc. and others related to the external environment, such as moisture, bacterial attack, stray currents, etc., which affect reinforcement corrosion (Castro et al., 1997). Uncontaminated cover concrete provides a physical barrier that prevents the direct exposure of the steel surface to the outside environment. It also provides a highly alkaline chemical environment that protects steel from corrosion.

\section{Literature Review}

Considerable research has been devoted to corrosion of reinforcement in reinforced concrete dealing with various issues related to corrosion process, its initiation and damaging effects. After the review of available literature and noting the areas where further work is needed, the following conclusion can be drawn;

- Ultimate load carrying capacity, deflection and stiffness of the RCC elements are reduced with increase in the degree of corrosion.

- Reduction in cross section of reinforcement, yield strength and cracks along the reinforcement are the main contributing factors for strength degradation of RCC element.

- As the degree of corrosion increased, the beam failure mode changed from ductile mode to brittle mode.

- To accelerate the corrosion process, generally current is impressed in the specimens immersed in electrolyte made with $3.5-5 \% \mathrm{NaCl}$ mixed in water.

- Salt spray method or alternate drying and wetting may also be used for induced corrosion.

- Small level of sustained load has little effect on rate of corrosion.

- The results of an accelerated corrosion tests on bare steel bars are in good qualitative agreement with results from steel bars embedded in aged concrete.

An attempt has been made in this study to review the literature available and to carry out experimental 
investigation effectively to determine the effect of corrosion on flexural capacity and performance of cantilever beam with a TMT bars as reinforcement.

\section{Objectives Of The Study}

The general objective of this work is to study the effect of reinforcement corrosion on the flexural strength of reinforced concrete beams.

- To induce accelerated corrosion on bare steel (TMT) bars, in the RCC beams and determine the effect of corrosion on its residual yield stress.

- Develop a test set up to carry out load-test on the cantilevered RCC beam.

- Study of residual flexural capacity of degraded reinforced concrete OPC beams due to corrosion and their effect.

\subsection{Test Program}

\section{Experimental Investigation}

Seventeen reinforced concrete cantilever beams with OPC of dimension $300 \mathrm{~mm} \times 400 \mathrm{~mm}$ in cross section and $2150 \mathrm{~mm}$ in length have been casted. The behavior of reinforced concrete beams of $2.5 \%, 5.0 \%$, and $7.5 \%$ corrosion will be studied. Five beams are casted as a control specimen (i.e., $0 \%$ corrosion). The details of experimental program, materials used, and method of testing is explained below.

\subsection{Materials}

The materials used for the experimental investigation are as follows.

$3 / 4 \quad$ Cement

$3 / 4 \quad$ Fine aggregates

$3 / 4 \quad$ Coarse aggregates

$3 / 4 \quad$ Reinforcing steel

$3 / 4 \quad$ Water

All the materials used for the experimental work were tested as per the codal provisions.

\section{Cement}

Ordinary Portland Cement (43 Grade) cement was used in the present investigation. It was tested as per IS: 8112-1989 recommendations for the cement. The results confirms the requirement as per IS code. The results are tabulated below.

Table: 4.2.1 Test results on Ordinary Portland cement

\begin{tabular}{|c|l|c|c|}
\hline S.No & \multicolumn{1}{|c|}{ Test Parameters } & Results & $\begin{array}{c}\text { (Specifications of 43 Grade } \\
\text { OPC cement) }\end{array}$ \\
\hline 1 & $\begin{array}{l}\text { Initial setting and } \\
\text { final setting time }\end{array}$ & $\begin{array}{c}70 \mathrm{~min} \text { and } 250 \\
\mathrm{~min}\end{array}$ & $\begin{array}{c}\text { Not less than } 30 \mathrm{~min} \text {. and } \\
\text { not more than } 600 \mathrm{~min}\end{array}$ \\
\hline 2 & Specific gravity & 3.14 & \multicolumn{2}{|c|}{} \\
\hline \multirow{2}{*}{3} & Compressive strength: $\mathrm{N} / \mathrm{mm}^{\wedge} 2$ & 26.57 & Not less than $23 \mathrm{~N} / \mathrm{mm}^{2}$ \\
\cline { 2 - 5 } & 3 Days & 36.41 & Not less than $33 \mathrm{~N} / \mathrm{mm}^{2}$ \\
\cline { 2 - 5 } & 28 Days & 45.84 & Not less than $43 \mathrm{~N} / \mathrm{mm}^{2}$ \\
\hline
\end{tabular}

Fine Aggregate

Physical tests on fine aggregates were conducted. The results are tabulated in Table: 4.2.2

Table: 4.2.2 Test results on Fine Aggregate

\begin{tabular}{|c|c|c|}
\hline \multicolumn{3}{|c|}{ Characteristics of fine aggregate (natural river sand) } \\
\hline Sno & Description & Value \\
\hline 1 & Specific gravity & 2.56 \\
\hline 2 & Water absorption & $2.61 \%$ \\
\hline 3 & Moisture content & $2.00 \%$ \\
\hline 4 & Grading & Zone-II \\
\hline
\end{tabular}




\section{Coarse Aggregate}

The size of the aggregate used was $20 \mathrm{~mm}$ downsize and $12.5 \mathrm{~mm}$ down size angular type coarse aggregate. Physical tests on coarse aggregates were conducted. Test results and combined sieve analysis are tabulated in table: 4.2 .3

Table: 4.2.3 Test results on Coarse Aggregate of 20mm down size

\begin{tabular}{|c|c|c|}
\hline \multicolumn{3}{|c|}{ Characteristics of Coarse aggregate 20mm down size } \\
\hline Sno & Description & Value \\
\hline 1 & Specific gravity & 2.66 \\
\hline 2 & shape & Angular \\
\hline 3 & Water absorption & $0.50 \%$ \\
\hline 4 & Moisture content & Nil \\
\hline
\end{tabular}

\section{Reinforcing Steel}

For determination of yield and tensile strength of tension bars, bar specimens of $12 \mathrm{~mm}, 16 \mathrm{~mm}$, and 20 $\mathrm{mm}$ diameter were tested in tension in a Universal Testing Machine and the complete load-elongation, hence stress-strain plots were obtained. From the stress-strain plots, yield strength and tensile strength of the bars were determined.

\section{Preparation Of Formwork}

The formwork was fabricated locally using 76.2/101.6-mm plywood and cast iron steel flats. The internal dimensions of the mould are exactly equal to specimen dimension. The formwork consisted of two Lshaped plywood sheets and one straight plywood sheet, which were connected by nuts and bolts through end wooden blocks as shown Fig.3.1. The internal surface of the formwork will properly oil for easy removal of specimen from the formwork.

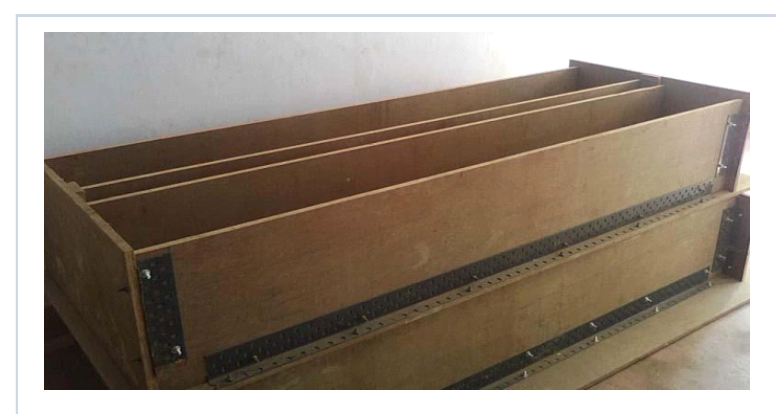

Fig.4.2.1 (a) Wooden Formwork

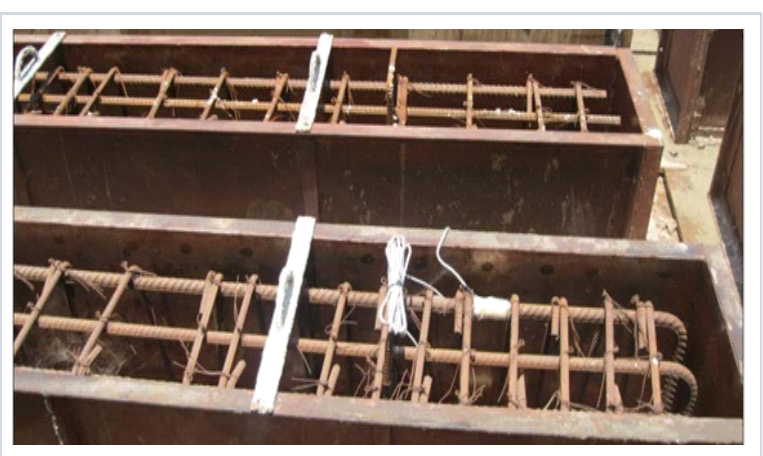

Fig.4.2.1 (b) Steel Formwork

\subsection{Concrete Mix Design \& Proportion}

Since huge amount of concrete is involved in the work, Ready Mixed Concrete is used in the preparation of the specimens. Based on the properties of the concreting materials many trials mix design is carried in the laboratory by varying the cement content, water cement ratio and amount of admixture to get the slump in the range of 80-120 mm and strength in the range of $20 \mathrm{MPa}$. The details of trial mixes carried out to 
determine the optimum mix proportion

The concrete mix for $\mathrm{M}_{20}$ Grade is prepared using OPC, fine sand and aggregate ( $20 \& 12.5 \mathrm{~mm}$ ) as per IS 10262:1982 "Recommended Guidelines for Concrete Mix Design" was followed.

Table: 4.3.1 Mix Proportion of M20 grade concrete

\begin{tabular}{|c|c|}
\hline Ingredients & Quantity \\
\hline Cement & $320.00 \mathrm{Kg} / \mathrm{m}^{3}$ \\
\hline Fine aggregate & $704.72 \mathrm{Kg} / \mathrm{m}^{3}$ \\
\hline Coarse aggregate & $1176.35 \mathrm{Kg} / \mathrm{m}^{3}$ \\
\hline Water & $164.80 \mathrm{Kg} / \mathrm{m}^{3}$ \\
\hline Admixture (Reo Build) & $0.7 \%$ of Cement \\
\hline Mix Proportion Ratio C : F.A : C.A :W & $1: 2.20: 3.67: 0.51$ \\
\hline
\end{tabular}

Table: 4.3.2 Trial mixes recommended for Beam preparation of M20 Grade Concrete with Admixtures

\begin{tabular}{|c|c|c|c|}
\hline Designation & Cement Brand & $\begin{array}{c}\text { Cement Content } \\
(\mathrm{Kg} / \mathrm{m} 3)\end{array}$ & Mix Proportions \\
\hline $\mathrm{Al}$ & $\mathrm{ACC}$ & 320 & $1: 2.26: 3.75$ \\
\hline $\mathrm{A} 2^{*}$ & $\mathrm{ACC}$ & 320 & $1: 22.24: 3.67$ \\
\hline $\mathrm{A} 3$ & $\mathrm{ACC}$ & 340 & $1: 2.09: 3.49$ \\
\hline $\mathrm{A} 4$ & $\mathrm{ACC}$ & 340 & $1: 2.04: 3.40$ \\
\hline $\mathrm{J} 1$ & $\mathrm{JK}$ & 320 & $1: 2.29: 3.70$ \\
\hline $\mathrm{J} 2^{*}$ & $\mathrm{JK}$ & 320 & $1: 2.27: 3.65$ \\
\hline $\mathrm{J} 3$ & $\mathrm{JK}$ & 340 & $1: 2.13: 3.44$ \\
\hline $\mathrm{J} 4$ & $\mathrm{JK}$ & 340 & $1: 2.1: 3.36$ \\
\hline
\end{tabular}

\subsection{Test Matrix}

Totally, 17 concrete beam specimens were casted. Four beams are to be tested for $2.5 \%, 5 \%$, and $7.5 \%$, of corrosion and also five beams are tested for $0 \%$.

\subsection{Reinforcement Configuration}

Two series of reinforced concrete cantilever beams of cross section $300 \mathrm{~mm} \times 400 \mathrm{~mm}$ and $2150 \mathrm{~mm}$ length have been cast. These cantilever beams have a shear span of $1750 \mathrm{~mm}$ and $400 \mathrm{~mm}$ bearing length. Beams with an effective cover of $30 \mathrm{~mm}$ are designed as per IS 456:2000. Beams are provided with two $20 \mathrm{~mm}$ diameter and one $16 \mathrm{~mm}$ diameter TMT (Fe 415) bars at top and same reinforcement is provided at bottom. Shear reinforcement of $12 \mathrm{~mm}$ dia TMT bars with a spacing of $150 \mathrm{~mm} \mathrm{c} / \mathrm{c}$ for a length of $1350 \mathrm{~mm}$ from the free end and $12 \mathrm{~mm}$ diameter TMT bars with a spacing of $75 \mathrm{~mm} \mathrm{c} / \mathrm{c}$ f or a length of $800 \mathrm{~mm} \mathrm{f}$ or remaining length of beam are adopted to ensure that flexural failure would dominate over shear failures shown in the Fig.4.5.1 (a), (b). 


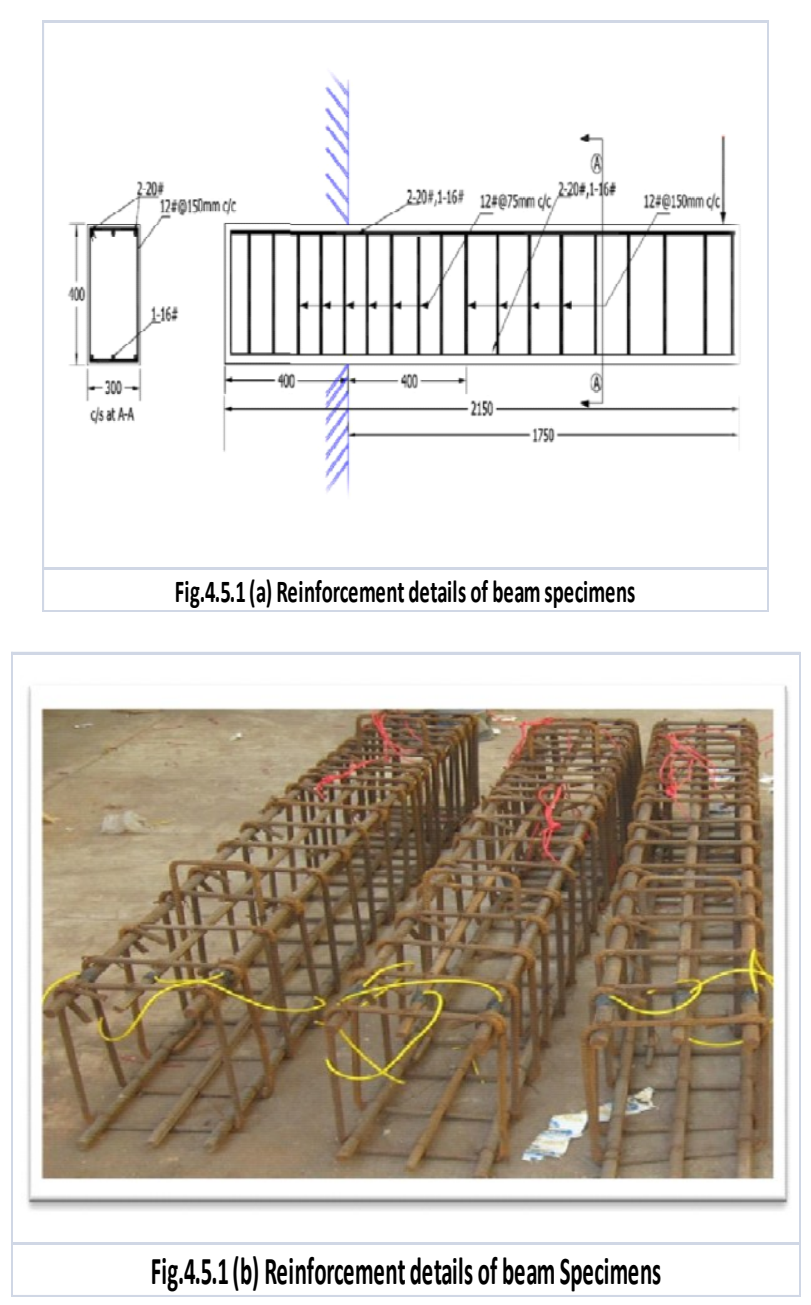

Different colors electrical wires are soldered to both the end of the main tension reinforcement bars before placing the concrete in the beam moulds. These wires are held in place so that it exited from the top face of the beam. At the free end, one yellow color, $4 \mathrm{~cm}^{2}$ multi-strand copper wires are connected to each reinforcement bar used to pass the electric current. Similarly at a distance of $300 \mathrm{~mm}$ from the fixed end, one red color, $2 \mathrm{~cm}^{2}$ multi-strand copper wires were connected to each reinforcement bar which was used to continuo us monitoring of the corrosion rate.

\subsection{Casting And Curing Of The Test Specimens}

Casting of 30 beam specimens was carried out in 4 batches. Six concrete cube specimens were also cast from each batch of concrete mix to deter mine the corresponding compressive strength. OPC concrete specimens concrete ingredients were mixed in a revolving drum type mixer $t$ ill it was uniform. The moulds were oiled and the steel reinforcement cages prepared beforehand were placed securely in their proper position in the moulds. $30 \mathrm{~mm}$ precast concrete cover blocks were used to maintain the $30 \mathrm{~mm}$ clear cover. The moulds were filled with concrete in three layers. After placement of each layer, the concrete was vibrated to ensure proper consolidation as shown in fig.4.6.1.

The specimens were demoulded after 24 hours of casting and then covered with wet gunny bags. For first two weeks after casting the beams were cured using wet gunny bags b y applying water frequently as shown in Fig.4.6.2 after 14 days of gunny bags curing the beam s were kept in a curing tank and cured for 14 days. After 28 days from casting the beams and the control specimens were stored to dry in atmosphere till test, after removing from the curing tank. 


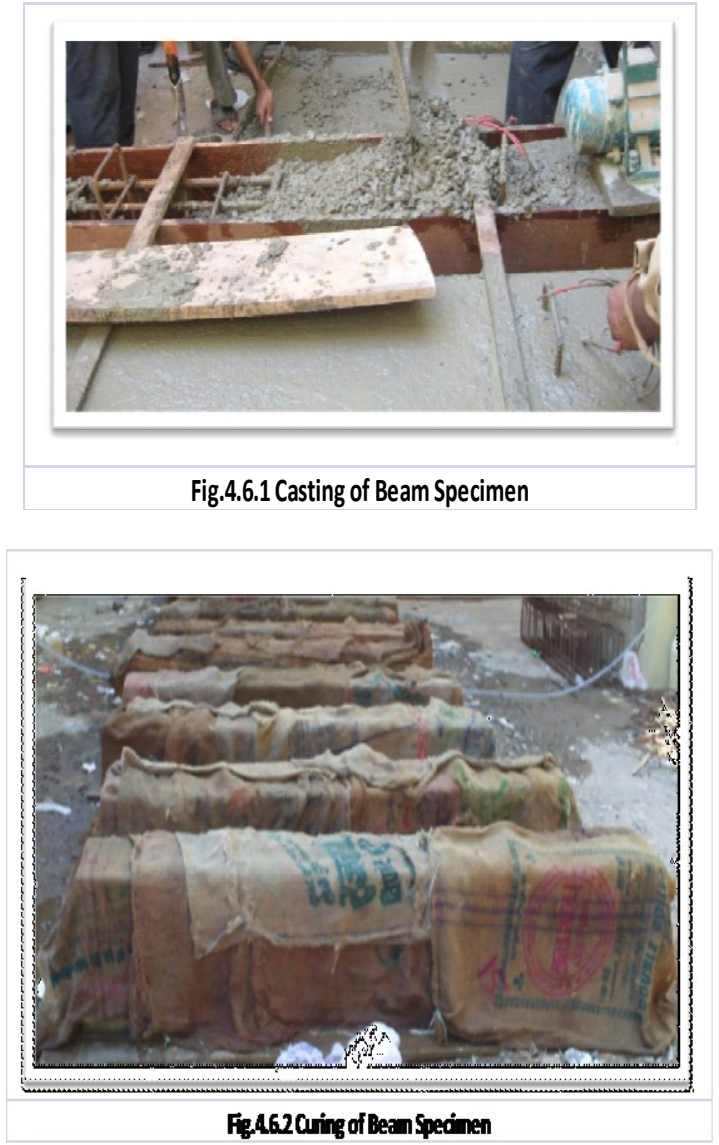

\subsection{Accelerated Corrosion Technique}

In this experiment the electrochemical corrosion technique is using to accelerate the corrosion of steel bars embedded in the specimens. To simulate the corrosion process, direct current is impressed on the bar embedded in the specimens using an integrated system incorporating a small direct current power supply with an in-built ammeter with an output of $64 \mathrm{~V}$ and $10 \mathrm{amps}$ to monitor the current. After specimens were immersed in a $5.0 \% \mathrm{NaC} 1$ solution for a day to en sure full saturation condition, the direction of current was arranged so that the steel bars in the specimens served as the anode. The stainless steel plate used as a cathode $\mathrm{w}$ as placed along the length of beam. This arrangement ensured a uniform distribution of $t$ he corrosion current along the whole length of the bar. A schematic representation of the test se t-up is shown in Fig.4.7.1. To obtain the desired levels of reinforcement corrosion, the current intensity and the electrifying time had to be controlled.

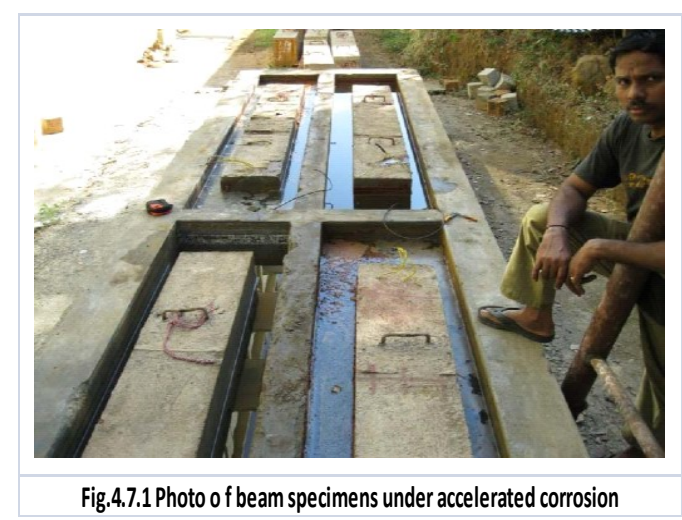

4.8 Time Required For Calculationing Different Percentage Of Corrosion

The current required for different degrees of corrosion is tabulated in the Table: 4.8.1 
Table: 4.8.1 Time calculation for different degree of corrosion

\begin{tabular}{|c|c|c|}
\hline $\begin{array}{c}\text { Percentage of } \\
\text { Corrosion }\end{array}$ & Current (Amps) & $\begin{array}{c}\text { Duration of } \\
\text { Corrosion } \\
\text { (Days) }\end{array}$ \\
\hline 2.5 & 10 & 6 \\
\hline 5 & 10 & 11 \\
\hline 7.5 & 10 & 20 \\
\hline
\end{tabular}

\subsection{Corrosion Rate Measurements}

To study the existing corrosion level of the beam specimens, initial current density was measured using the corrosion measuring system "Gill AC". The beam specimens were divided into number of grids to locate the guard ring $\mathrm{p}$ robe to polarize the definite area on concrete rebar as shown in the fig 4.9.1. At each node, corrosion current density $\mathrm{w}$ as measure $\mathrm{d}$ by LPR technique. The current density for each control specimen is shown in the Table 4.9.1

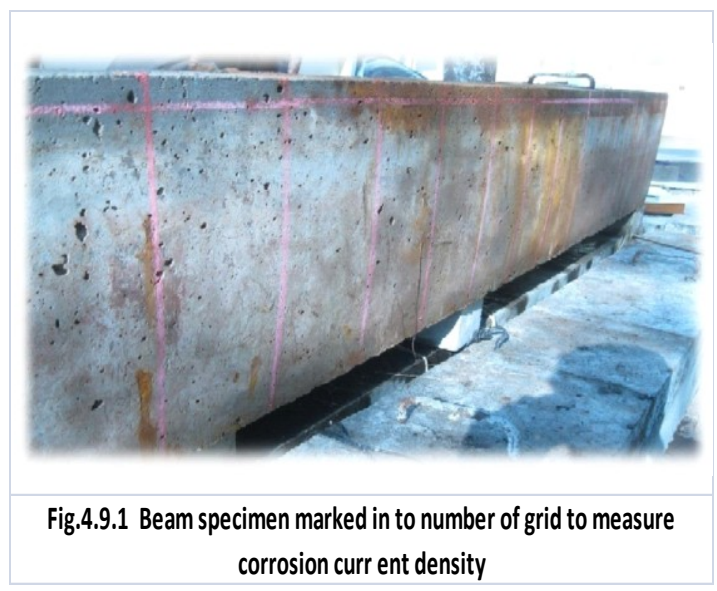

Table 4.9.1 Corrosion current density of Control Specimens

\begin{tabular}{|c|c|c|c|c|c|c|c|}
\hline & & \multicolumn{6}{|c|}{ Corrosion current density, $i_{\text {corr }}\left(\mathrm{mA} / \mathrm{cm}^{2}\right)$} \\
\hline & Grid Number & 1 & 2 & 3 & 4 & 5 & Avg \\
\hline \multirow{8}{*}{ Beams } & Control Beam & 0.0037 & 0.0038 & 0.0042 & 0.0039 & 0.0042 & 0.0039 \\
\hline & $\begin{array}{c}2.5 \% \text { Corroded } \\
\text { Beam }\end{array}$ & 0.031 & 0.03307 & 0.02599 & 0.02482 & 0.06059 & 0.0351 \\
\cline { 2 - 8 } & $\begin{array}{c}5 \% \text { Corroded } \\
\text { Beam }\end{array}$ & 0.0438 & 0.05326 & 0.0356 & 0.0432 & 0.0468 & 0.0409 \\
\hline & $\begin{array}{c}7.5 \% \text { Corroded } \\
\text { Beam }\end{array}$ & 0.0623 & 0.06826 & 0.0658 & 0.07082 & 0.072 & 0.067 \\
\hline
\end{tabular}

\section{Testing Setup}

Flexural testing of the cantilever beam was carried out under the specially prepared loading frame. Loading set up was constructed in the existing reaction bed at laboratory to test the beam as a vertical cantilever by applying point load at the free end of the beam in transverse direction. To achieve the fixity at the fixed end of the beam, heavy duty hydraulic jack was used against the steel column section at the other side of the beam. Full fixity was achieved at the bottom end of the beam by adjusting the movement of the hydraulic jack arm. The loading frame are designed as a steel space frame, Built up section made up of two ISMC-100 sections with face to face was used to construct the loading frame. $16 \mathrm{~mm}$ diameter hilty bolts of $40 \mathrm{kN}$ capacities were grouted on the reaction bed to fix the loading frame to the reaction bed. The loading frame was designed to carry a $100 \mathrm{kN}$ concentrated load, which is the expected reaction from the beam element.

All beams are tested as cantilever beams in a 15 tonne capacity steel testing frame made up of rolled steel joists, the beam having a span of $1850 \mathrm{~mm}$ was fixed at one end for a bearing length of $400 \mathrm{~mm}$. The span 
and load points are kept constant for all the beams. The concentrated load is applied on the free end of a beam. The load spreader arm, wherever used is a rolled steel joist which is supported on the rollers kept on the loading points. Over the load spreader arm the proving ring of 20 tonnes capacity which is used to measure the applied load, is placed over which the hydraulic jack of 20 tonnes was fixed to the rolled steel joist of the loading frame. The pump of a hydraulic jacks operated by a hand lever. Fig.5.1 shows the test set up with beam specimen.

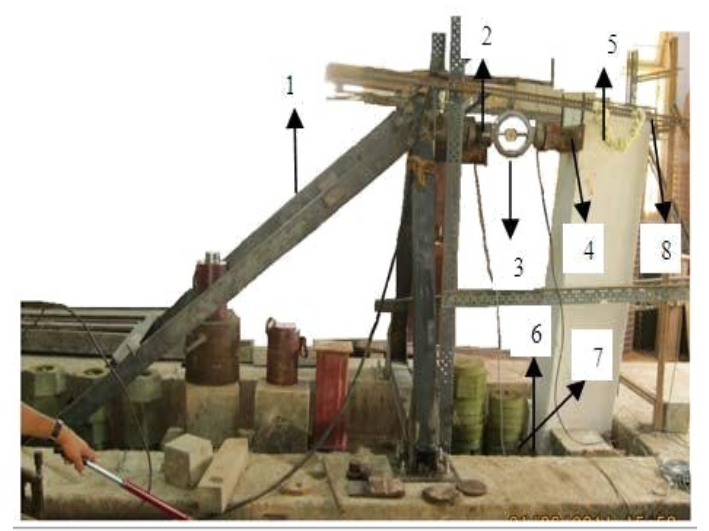

Fig.5.1 Test set up tor beam specimen

\section{Results And Discussions}

The RC beam specimens were casted as specified. In t he present study 5 control specimens and 12 uncontrolled specimen $(2.5 \%, 5 \%, 7.5 \%$ of corrosion) prepared with OPC mix were tested as a cantilever beam, in the specially prepared loading set up, to determine the flexural capacity. Hydraulic jack was used to fix the beam bottom to the reaction bed. Here we measure d deflection, strain, and crack using dial gauge, strain gauge and crack measuring microscope respectively.

During the testing of control beam (CB1 to CB5), it was observed that the control beams failed in flexure at an ultimate load, $92.09 \mathrm{kN}$ and for $2.5 \%$ corroded beams failed at a $\mathrm{n}$ ultimate load $87.83 \mathrm{k} \mathrm{N}$ remaining $5 \%, 7.5 \%$ corroded beams showing the failure at $86.17 \mathrm{k} \mathrm{N}, 72.14 \mathrm{kN}$ respectively. As the load increases the cracks developed throughout the width of $\mathrm{t}$ he beam. Fig 6.1 illustrates the failure modes of all beams. It was observed that controlled beam attained the highest flexural load capacity, followed by $2.5 \%, 5 \%$, 7.5\%. Fig 6.2 shows the Deflection of beam after Flexure failure.

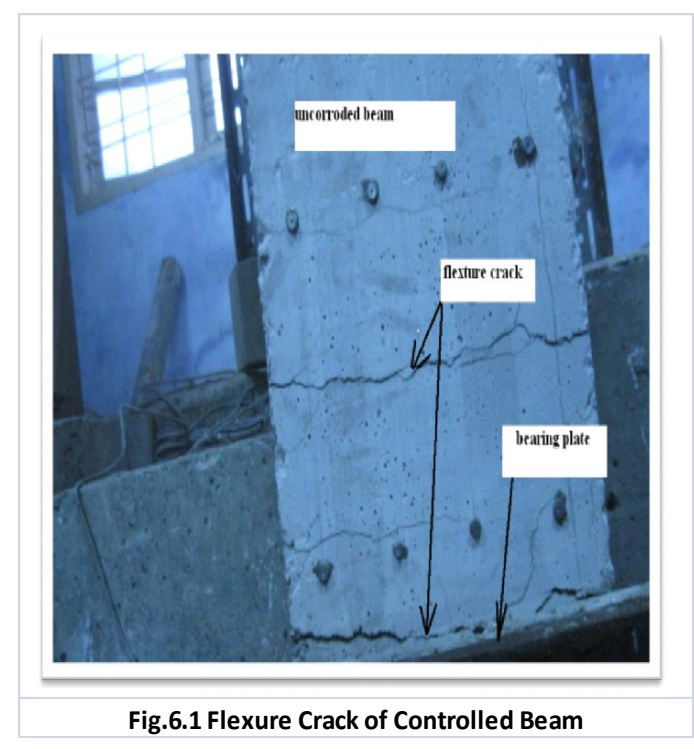

As the load was applied flexural cracks were initiated from the bottom of beam in the region of maximum moment. When the load beyond the yield strength of beam was applied, these cracks were widened and extended to the sides and new flexural cracks formed. As the applied load was further increased, cracks width increases and beam failed in flexure. The moment of resistance provided by the reinforcement was controlled by the anchorage (bond) of the bars and its magnitude was less than that provided by fully bonded reinforcement bars that yield at failure.

The corroded beams was not much effective in attain the beam load carrying capacity in beams $5 \%$, 
$7.5 \%$, But in case of $0 \%$, which was most effective in attain the load carrying capacity. When compared to the controlled beam specimen, $2.5 \%, 5 \%$ and $7.5 \%$ corroded beam specimen takes $7 \%$ and $25 \%$ less load.

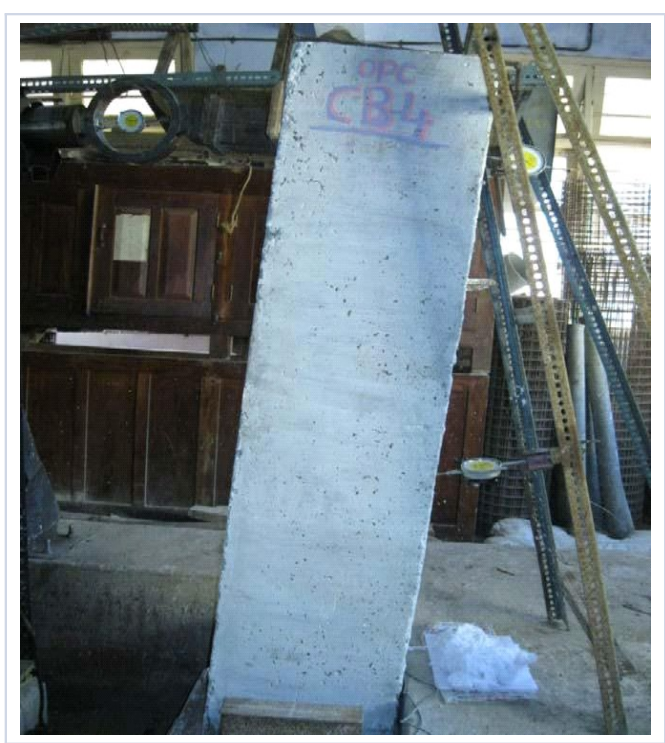

Fig.6.2 Deflection of beam after Flexure failure

Table no: 6.1 Ultimate Load \& Deflection for Different Percentages of Corrosion of Beams

\begin{tabular}{|c|c|c|c|c|}
\hline $\begin{array}{c}\text { Beam } \\
\text { Specimen }\end{array}$ & $\begin{array}{l}\text { Ultimate } \\
\text { Load(kN) }\end{array}$ & $\begin{array}{c}\text { Average } \\
\text { Ultimate Load } \\
(\mathrm{KN})\end{array}$ & $\begin{array}{c}\text { Deflection } \\
(\mathrm{mm})\end{array}$ & $\begin{array}{c}\text { Average } \\
\text { Deflection } \\
(\mathrm{mm})\end{array}$ \\
\hline \multirow{4}{*}{$0 \%$} & 92.8 & \multirow{4}{*}{92.09} & 60.67 & \multirow{4}{*}{60.59} \\
\hline & 90.91 & & 61.58 & \\
\hline & 93.75 & & 59.58 & \\
\hline & 90.9 & & 60.56 & \\
\hline \multirow{4}{*}{$2.50 \%$} & 89.96 & \multirow{4}{*}{87.83} & 100.35 & \multirow{4}{*}{74.35} \\
\hline & 86.17 & & 47.23 & \\
\hline & 85.23 & & 73.91 & \\
\hline & 89.96 & & 75.91 & \\
\hline \multirow{4}{*}{$5 \%$} & 89.86 & \multirow{4}{*}{86.17} & 82.36 & \multirow{4}{*}{65.77} \\
\hline & 85.23 & & 40.01 & \\
\hline & 84.28 & & 61.18 & \\
\hline & 85.23 & & 79.56 & \\
\hline \multirow{4}{*}{$7.50 \%$} & 72.38 & \multirow{4}{*}{72.14} & 55.4 & \multirow{4}{*}{57.24} \\
\hline & 76.19 & & 65.65 & \\
\hline & 68.57 & & 52.16 & \\
\hline & 71.43 & & 55.76 & \\
\hline
\end{tabular}

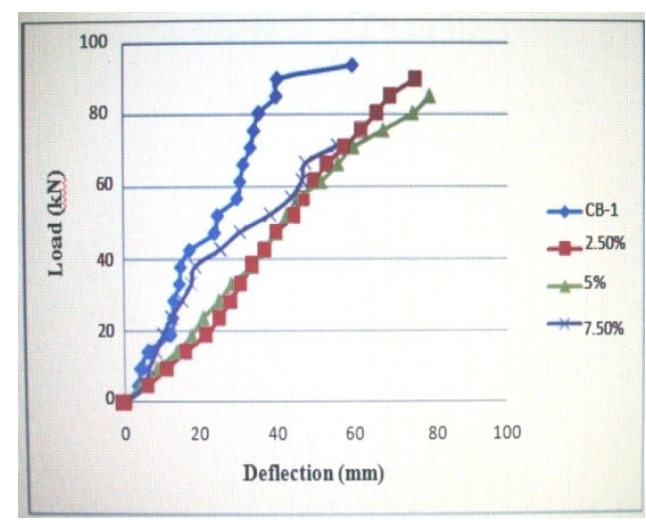

Graph 6.1 Load vs. End Beam Deflection 


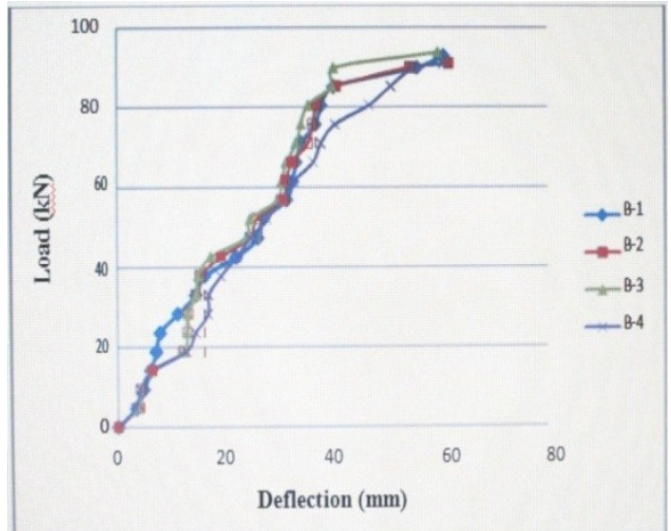

Graph 6.2 Load vs. End Beam Deflection (Control Beam)

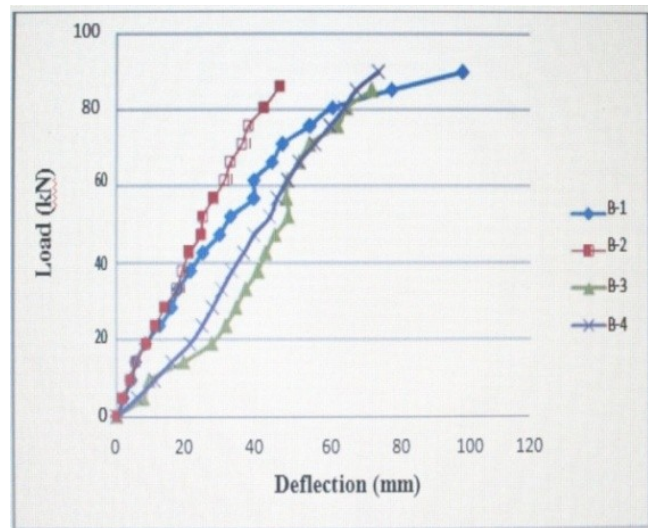

Graph 6.3 Load vs. End Beam Deflection (2.5\% Corroded Beam)

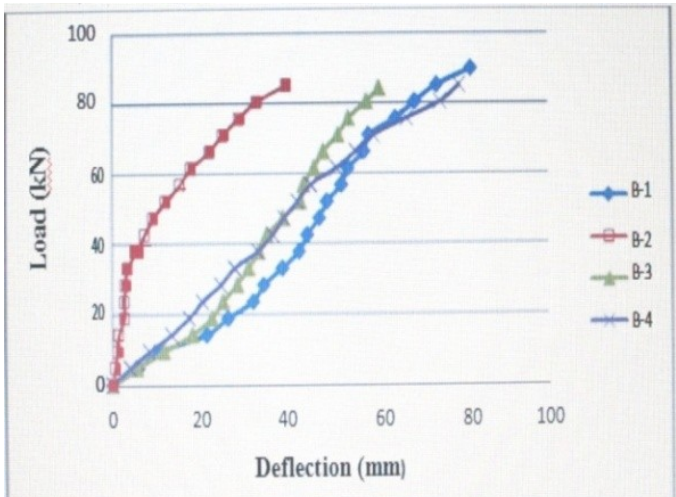

Graph 6.4 Load vs. End Beam Deflection (5\% Corroded Beam)

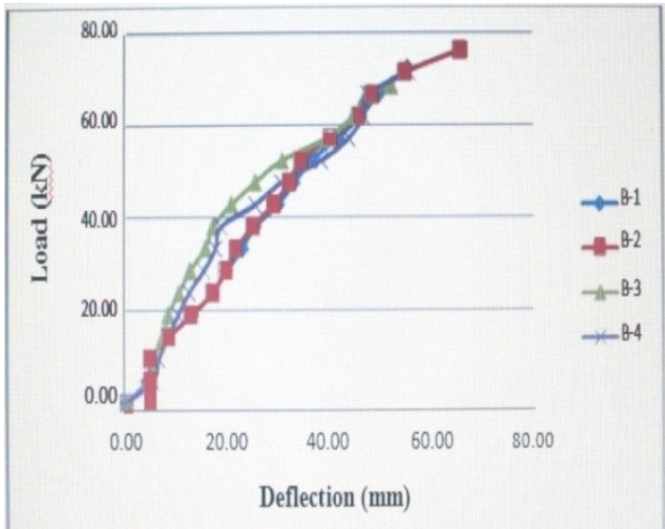

Graph 6.5 Load vs. End Beam Deflection (7.5\% Corroded Beam) 
- It is observed that for Control Beams (i.e., Non-Corroded Beams),Peak load taken was maximum compared with 2.5\%,5\%,7.5\%.Deflection observed for Control Beam was less than Corroded Beams.

- For Beams Corroded (i.e, $2.5 \%, 5 \%$ ), the Peak load taken by Beams was less than Non-Corroded Beams, but the Deflection observed for Corroded Beams $(2.5 \%, 5 \%)$ was more.

- It is observed that for 7.5\% Corroded Beams, the Peak load taken by the Beam was less compared with (i.e., $2.5 \%, 5 \%$ ), Control Beams and Deflection was also less.

\section{Corrosion Crack Patterns}

The effect of uniform corrosion, causing extensive cracking, staining and spalling of concrete cover. In this crack width measured using Crack Microscope with an accuracy of $0.02 \mathrm{~mm}$. The initiation of corrosion is likely to occur at the stirrup reinforcement surface which has the minimum concrete cover. In Corroded beams red and brownish-red colored rusts were observed in different amounts and at different locations. All corroded beams developed surface cracks. The crack pattern seen in Corroded specimen, the crack that propagated perpendicular to the corroded steel bars was observed on the extreme tensile face of the beam to where corrosion agents drawn into the concrete. These cracks were observed at intervals ranging from $72 \mathrm{~mm}$ to $86 \mathrm{~mm}$ intervals, from fixed end to a length of $450 \mathrm{~mm}$ to $630 \mathrm{~mm}$ towards the top. It is observed that some of the cracks as they propagate split into two and few such cracks cross the side face and propagate further. In this cracks split into two and the split cracks then crossed to the side faces and propagated and also perpendicular to the corroded bars. The majority of beams in this research (uncontrolled) exhibited this crack pattern. As the load increases crack width also increases. In case of controlled beam, at the extreme tensile face only some cracks are split in to two and the cracks were observed from fixed end to a length $220 \mathrm{~mm}$ to $400 \mathrm{~mm}$ towards the top. In control beam $(0 \%)$ the first cracks observed at the load $37.87 \mathrm{kN}$, the maximum crack width is between $0.40 \mathrm{~mm}$ and 0.5 $\mathrm{mm}$ and in $2.5 \%$ corroded beam specimen, first crack developed was similar to controlled specimen and the maximum crack varies $0.45 \mathrm{~mm}$ to $0.50 \mathrm{~mm} .5 \%$ beam specimen develop the first crack at load $37.87 \mathrm{kN}$, here crack width increased $11 \%$ than the controlled specimen. In $7.5 \%$ corroded specimen shows the first crack width at the load $33.14 \mathrm{kN}$, in this out of four specimen one specimen crushed at the bottom, maximum crack width varies $0.55 \mathrm{~mm}$ to $0.58 \mathrm{~mm}$ it was observed that this crack $17 \%$ more than the controlled specimen. Corrosion crack pattern of corroded specimen as shown in Fig 7.1

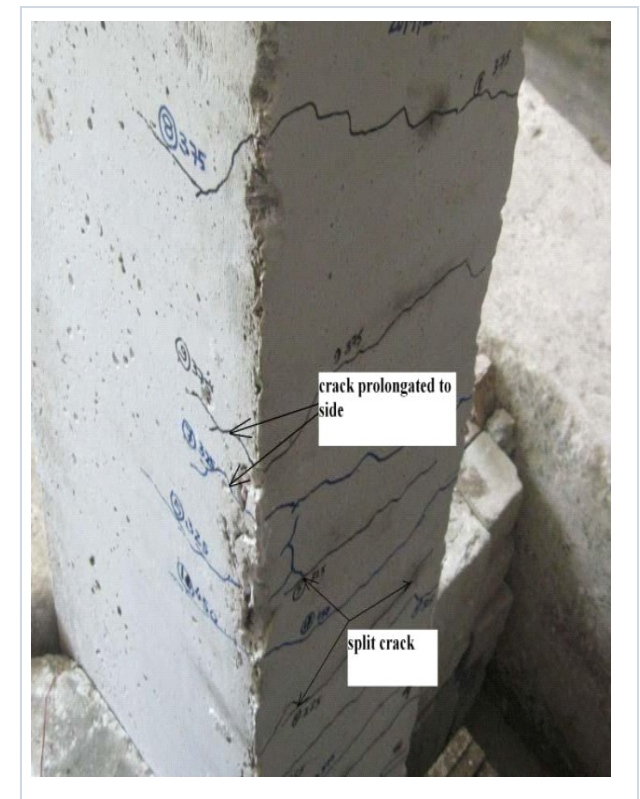

Fig.7.1 Tension cracks pattern in the Corroded Beam

\section{Conclusions}

- From the experimental investigation it is observed that the load carrying capacity of the beam is more for control beams, but Deflection is less for Control beams with respect to Corroded beams $(2.5 \%, 5 \%$, and $7.5 \%)$.

- It is concluded that, as the rate of corrosion increases above $5 \%$, the Ductility property of beam specimen goes on reducing.

- It is observed that the Moment Carrying Capacity of control beams is more, with respect to Corroded beams $(2.5 \%, 5 \%$, and $7.5 \%)$ 
- The peak load and the Strains sustained by the Control beams is more than the Corroded beams

- The Moment Carrying Capacity was less for corroded Beams with respect to Control Beams. But the Curvature observed was more for Corroded Beams.

- The number of cracks developed is more in case of Control Beams as that of Corroded Beams, but as the rate of corrosion increases the crack width increases in Corroded Beams than in Control Beams.

\section{Scope For Future Work}

- Tests should be carried out on different beam sizes to verify the accuracy of the proposed method and to observe the size effect.

- The predictive model can be developed on the basis of test data generated from beams of same size.

- Study should be carried out in different exposure conditions such as, natural corrosion and sea corrosion, to study the effect of corrosion on strength and durability aspects of structures.

\section{References}

[1]. Ahmad, S. (2003). "Reinforcement corrosion in concrete structures, its monitoring and service life prediction-a review" Journal of Cement \& Concrete Composites.”25, 459-471.

[2]. Ahmad, S. (2009). "Techniques for inducing accelerated corrosion of steel in concrete" The Arabian Journal for Science and Engineering." 34, 156-169.

[3]. Almusallam, A. (2001). "Effect of degree of corrosion on the properties of reinforcing steel bars" Journal of Construction and Building Materials." 15, 361-368.

[4]. Andrade, C. and Alonso, C., (1996) "Corrosion rate monitoring in the laboratory and on site". Journal of Construction building materials, 10, 315-28.

[5]. Andres, A., Gitierrez, S., Guilen, J. (2007). "Residual flexure capacity of corroded reinforced concrete beams" Journal of Engineering Structures, 29, 1145-1152.

[6]. Apostolopoulos, C.A. and Papadakis, V.G. (2009). "Consequences of steel corrosion on the ductility properties of reinforcement bar" Journal of Construction and Building Materials, 22, 2316-2324.

[7]. Azher, S. A., (2005) "A Prediction Model for the Residual Flexural Strength of Corroded Reinforced Concrete Beams", M.S thesis submitted to King Fahd University of Petroleum \& Minerals, Saudi Arabia..

[8]. Capozucca, R. (1995). "Damage to reinforced concrete due to reinforcement corrosion." Construction and Building Marerial, 9 (5), 295-303.

[9]. Fontana, M.G. (2005). Corrosion engineering, Tata McGraw-Hill Education Private Limited, New Delhi.

[10]. Gelany, M.A., (2001) "Short-term corrosion rate measurement of OPC and HPC reinforced concrete specimens by electrochemical techniques". Materials and Structures, 34, 426-32

[11]. Manoharan, R., Jabalan, P., Palanisamy., (2008), "Experimental Study on Corrosion Resistance of TMT Bar in Concrete", International conference on building construction and construction, 22, 239-250

[12]. Parande, A.P., Dhayalan, M. S. Karthikeyan, K. Kumar and Palaniswamy, N. (2008), “Assessment of Structural Behavior of Noncorroded and Corroded RCC Beams Using Finite Element Method”, Sensors and Transducers Journal, 96 (9), $121-136$.

[13]. Park, R., and Paulay, T. (1975), Reinforced Concrete Structures, John Wiley \& Sons, Inc. New York

[14]. Pillai, S.U. and Menon, D. (2009), Reinforced Concrete design, Tata McGraw-Hill Education Private Limited, New Delhi.

[15]. Pradhan, B. and Bhattacharjee, B. (2009) "Performance evaluation of rebar in chloride contaminated concrete by corrosion rate", Construction and Building Material”, 23, 2346-2356

[16]. Revathy, J. Suguna, K. and Raghunath, P.N. (2009). "Effect of corrosion damage on the ductility performance of concrete columns" India American Journal of Engineering and Applied Sciences, 2, 324-327.

[17]. Rodriguez, J., Ortega, L., Garcia, A. (1994). "Corrosion of reinforcing bars and service life of R/C Structures: corrosion and bond deterioration. In: Concrete across Borders", Proceedings, Odense, Denmark, 2, 315-326.

About Authors:
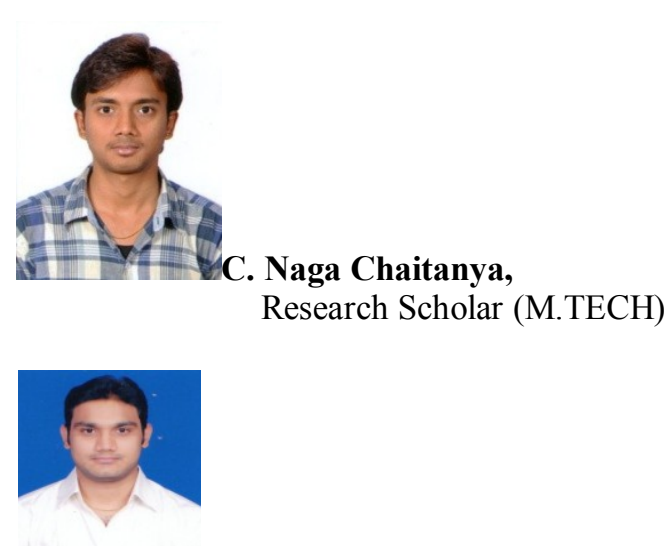

B. Vamsi Krishna, M.S

Assistant Professor, Structural Engineering 